\title{
PENGARUH MODEL PEMBELAJARAN GENERATIF TERHADAP PEMECAHAN MASALAH MATEMATIKA PADA MATERI PERSAMAAN LINIER DUA VARIABEL KELAS X SMK SWASTA ASAHAN KISARAN TAHUN PELAJARAN 2018/2019
}

\author{
Regina Sabariah Sinaga \\ STKIP Budidaya Binjai \\ reginasabariah@gmail.com
}

\begin{abstract}
ABSTRAK
Penelitian ini merupakan penelitian eksperimen yaitu pengaruh model pembelajaran generative terhadap pemecahan masalah matematika pada materi persamaan linear dua variabel. Tujuan penelitian ini untuk mengetahui pengaruh model pembelajaran generative terhadap pemecahan masalah matematika pada materi persamaan linear dua variabel di kelas X SMK Swasta Asahan Kisaran. Populasi dalam penelitian ini adalah siswa kelas X SMK Swasta Asahan Kisaran yang berakreditasi dengan sampel kelas X AK (kelas eksperimen) dan XAP (kelas kontrol), masing-masing terdiri dari 30 siswa. Instrumen dalam penelitian ini berupa uraian. Tes yang diberikan telah memenuhi kreteria validitas, reabelitas, daya pembeda, tingkat kesukaran, setelah data dikumpul kemudian dianalisis. Pengujian persyaratan anlisis data meliputi uji normalitas data dengan menggunakan uji Lilliefors dan uji homogenitas data dengan menggunakan uji $\mathrm{F}$. Pengujian hipotesis menggunakan uji t. Berdasarkan hasil data post tes diperoleh rata- rata pemecahan masalah matematika siswa yang di ajarkan dengan menggunakan model pembelajaran generative adalah 88,43 dan kelas control 65,43. Hasil perhitungan uji hipotesis diperoleh harga $t_{\text {hitung }}=3,74$, dengan melihat tabel nilai $\mathrm{t}$ dengan taraf nyata $\alpha=0,05$ diperoleh $\mathrm{t}_{\text {tabel }} 1,67$. Harga $\mathrm{t}_{\text {hitung }}=$

$3,74>t_{\text {tabel }}$ 1,67 dapat disimpulakan bahwa kemampuan pemecahan masalah matematika siswa yang diajarkan dengan menggunakan model pembelajaran generative lebih baik dari pada kemampuan pemecahan masalah matematika siswa yang diajarkan dengan menggunakan model konvensional dalam materi persamaan linear dua variabel.
\end{abstract}

Kata Kunci : model pembelajarn generative, kemampuan pemecahan masalah 


\section{PENDAHULUAN}

\section{Latar Belakang Masalah}

Pemecahan masalah merupakan kurikulum matematika yang sangat penting karena dalam proses pembelajaran maupun penyelesaian, siswa dimungkinkan memperoleh pengalaman menggunakan pengetahuan serta keterampilan yang sudah dimiliki untuk diterapkan pada pemecahan masalah yang bersifat tidak rutin dimana dalam pemecahan masalah kemampuan pemahaman konsep harus dikuasai siswa. Pemecahan masalah merupakan kemampuan dasar yang harus dikuasai oleh siswa. Bahkan tercermin dalam konsep kurikulum berbasis kompetensi. Tuntutan akan kemampuan pemecahan masalah dipertegas secara emplisit dalam kurikulum tersebut, yaitu sebagai kompetensi dasar yang harus diintegrasikapada sejumlah materi yang sesuai.

Pada awal abad ke sembilan belas, pemecahan masalah dipandang sebagai kumpulan keterampilan bersifat mekanis, sistematik, dan seringkali abstrak sebagaimana keterampilan yang digunakan pada penyelesaian soal sistem persamaan. Penyelesaian masalah seperti ini seringkali hanya berlandaskan pada solusi logis yang bersifat tunggal (Kirkley, 2003). Dengan adanya pengaruh teori belajar kognitif, maka terjadi pula perubahan pandangan terhadap makna pemecahan masalah yang mengarah pada aktivitas mental bersifat kompleks meliputi berbagai keterampilan dan aksi kognitif. Menurut Garofalo dan Lester (dalam Kirkley, 2003), pemecahan masamasah mencakup proses berpikir tingkat tinggi seperti proses visualisasi, asosiasi, abstraksi, manipulasi, penalaran, analisis, sintesis, dan generalisasi yang masing-masing perlu dikelola secara terkoordinasi. Pada tahun enam puluhan sampai tujuh pluhan, para ahli pendidikan matematika mencoba mengembangkan model pemecahan masalah umum untuk menjelaskan proses yang terjadi pada pemecahan masalah (Newel dan Simon, 1972; Polya, 1957; Bransford dan Stein, 1984).

Matematika merupakan suatu mata pelajaran yang diajarkan pada setiap jenjang pendidikan mulai dari sekolah Dasar (SD) sampai dengan Sekolah Menengah Atas (SMA), bahkan Perguruan Tinggi. Hal ini memperlihatkan bahwa bidang studi matematika penting dalam pendidikan, bahkan bukan hanya dalam dunia pendidikan, matematika juga sangat penting dalam kehiupan. Begitu banyak alasan yang menjadikan matematika menjadi salah satu bidang studi yang harus ada.

Matematika sering dianggap sebagai pelajaran yang paling sulit dipahami. Sehingga siswa kurang berminat untuk belajar matematika. Siswa kurang memperhatikan pada pelajaran ini karena siswa menganggap matematika itu pelajaran yang mempunyai soal - soal yang sulit untuk dipecahkan. Pada saat pelajaran siswa dapat mengikutinya, tetapi dalam mengerjakan latihan atau diberi pertanyaan sisa belum mampu untuk berfikir sendiri bagaimana menyelesaikan permasalahan tersebut. Sehingga untuk meningkatkan kemandirian siswa dalam berfikir kearah yang lebih tinggi sangat sulit dicapai. Kenyataan sekarang banyak dijumpai selama ini adalah ketidaksukaan sisa pada matematika menyebabkanSiswa enggan mengerjakan soal - soal yang diberikan guru. Ini mengakibatkan kemampuan pemecahan masalah matematika siswa rendah. Padahal dari soal - soal tersebutlah siswa dapat melatih kemampuannya dalam memecahkan masalah yang ada pada setiap tipe soal marematika. 
Faktor - faktor ini tarkait dimana faktor guru dan peserta didik menjadi hal yang sangat berpengaruh dalam proses belajar. Salah satunya ditekankan penulis adalah model pembelajaran yang digunakan guru. Pemilihan model pembelajaran perlu memperhatikan beberapa hal, seperti materi yang disampaikan, tujuan, waktu yang tersedia, siswa serta hal-hal yang berkaitan dengan proses belajar mengajar.

Model pembelajaran merupakan faktor penting dalam proses belajar matematika siswa. Lebih tepatnya seorang guru dalam memilih suatu model akan sangat berpengaruh terhadap keberhasilan proses belajar mengajar, karena model pembelajaran merupakan cara yang tepat dan telah direncanakan dengan baik oleh guru dalam menyampaikan materi pembelajaran sehingga tercapai tujuan pembelajaran yang diharapkan. Salah satu fokus pembelajaran meningkatkan kemampuan metematika melalui pembelajaran yang berawal dari suatu pengalaman siswa yang terjadi dalam kehidupan sehari - hari. Tetapi pada kenyataan, banyak siswa yang mengalami kesulitan dalam memecahkan masalah matematika.

Berdasarkan hal tersebut, maka peneliti mencoba mengupayakan model pembelajaran yang tepat, sesuai dengan tingkat perkembangan mental siswa dan dapat membuat siswa menjadi lebih aktif. Salah satunya adalah dengan menerapkan model generatif. Model pembelajaran generatif memiliki empat tahap yaitu: (1) tahap eksplorasi atau tahap penahuluan, (2) tahap pemfokusan, (3) tahap tantangan atau tahap pengenalan konsep, dan (4) tahap penerapan konsep.

Dengan tahap-tahap pembelajaran tersebut, siswa diharapkan memiliki pengetahuan, kemampuan serta keterampilan untuk membangun pengetahuan secara mandiri.
Dengan pengetahuan awal yang telah dimiliki sebelumnya dan menghubungkannya dengan konsep yang dipelajari, akhirnya siswa mampu membangun pengetahuan baru.

Berdasarkan penjelasan diatas, maka penulis tertarik untuk mengadakan penelitian dengan judul: "Pengaruh Model Pembelajaran Generatif Terhadap Kemampuan Pemecahan Masalah Matematika Pada materi Persamaan Linier Dua Variabel pada Kelas X SMK Swasta Asahan Kisaran TP. 2018/2019" TujuanPenelitian

Adapun yang menjadi tujuan penelitian ini adalah : "Untuk mengetahui pengaruh model pembelejaran generatif terhadap kemampuan pemecahan masalah matematika pada materi persamaan linear dua variabel pada siswa kelas $\mathrm{X}$ di Tahun Pelajaran 2018/2019"

\section{Manfaat Penelitian}

Melalui penelitian ini diharapkan dapat bermanfaat bagi semua kalangan, diantaranya:

1. Bagi guru matematika sebagai informasi tentang pemilihan model pembelajaran.

2. Bagi siswa untuk memperoleh pengalaman langsung tentang model pembelajaran langsung generatif pada materi persamaan linier.

Bagi kepala sekolah sebagai informasi untuk pengambilan kebijakan tentang penggunan model pembelajaran.

\section{METODE PENELITIAN}

Penelitian dilaksanakan di SMK

Swasta Asahan Kisaran Tahun Ajaran 2018/2019. Waktu penelitian langsung pada bulan September 2019. Populasi penelitian 
ini adalah seluruh siswa kelas X SMK Asahan Kisaran tahun pelajaran 2018/2019, yang terdiri dari dua kelas dengan jumlah 30siswa. Sampel dari penelitian ini terdiri dari dua kelas yang berjumlah 30 orang, yaitu kelas X-AK sebagai kelas Eksperimen tediri dari 15 siswa dan kelas $\mathrm{X}$-AP sebagai kelas kontrol terdiri dari 15 siswa.

\section{Variabel Peneliti}

Dalam penelitian ini menggunakan dua variabel yakni variabel bebas dan variael terikat. Sehingga variabel bebas adalah model pembelajaran generatif tipe Generative Learning dan kontrol, sedangkan variabel terikat adalah kemampuan pemecahan matematika siswa pada pokok bahasan sistem pesmaan linear dua variabel

\section{Desain Penelitian}

Desain penelitian yang digunakan adalah desain kelompok kontrol dan Eksperimen posttest (Two Randomized Subject Posttest Only ). Untuk lebih jelasnya desain penelitian digambarkan pada tabel berikut:

Langkah-langkah yang dilakukan sebagai berikut:

1. Peneliti mengadakan pemilihan kelas eksperimen dan kelas kontrol.

2. Peneliti mengadakan pretes awal pada siswa untuk melihat apakah kedua kelas homogen.

3. Peneliti melaksanakan pembelajaran menggunakan model pembelajaran Generatif di kelas Eksperimen dan untuk kelas kontrol dengan menggunakan pembelajaran konvensional dengan materi yang sama yaitu persamaan kuadrat.

3. Peneliti menggunakan postes akhir dengan soal yang setara pada setiap kelas

4. Data yang diperoleh dari kedua kelas yang diteliti, kemudian dianalisis sehingga dapat digunakan dalam uji hipotesis.

5. Dari hasil pembahasan penelitian, akan diperoleh temuan dan kesimpulan penelitian.

\section{InstrumenPenelitian}

Tes yang digunakan dalam penelitian ini adalah tes pemahaman konsep dalam bentuk soal-soal essay yang terdiridari 5 soal essay. Sebelum dilaksanakan penelitian kepada sampel, tes yang telah disusun terlebih dahulu diujicobakan, dengan langkah-langkah menghitung indeks kesukaran, daya pembeda, tingkat validitas dan tingkatreliabilitas.

\section{HASIL DAN PEMBAHASAN Hasil}

Populasi dalam penelitian ini adalah seluruh siswa kelas X SMK Swasta Asahan Kisaran. Penelitian ini diambil seluruh jumlah populasi untuk digunakan sebagai sampel penelitian terdiri dari 2 kelas, yaitu kelas XAK sebagai kelas eksperimen dan X-AP sebagai kelas control.

Sebelum pengumpulan data dilakukan terlebih dahulu instrument pengumpulan data diajukan dikelas X-AK dan X-AP SMK Swasta Asahan Kisaran yang terlebih dahulu selesai mempelejari materi persamaan linear dua variabel, Instrument pengumpulan data ini diuji untuk melihat validitas, reabilitas, daya pembeda soal, dan tingkat kesukaran soal.

Sebelum diberikan tindakan diperoleh rata-rata pretest siswa kelas kontrol sebesar 28,20 dengan simpangan baku 7,814, setelah diajarkan dengan menggunakan model pembelajaran generative dari hasil posttest diperoleh data rata-rata kemampuan pemecahan masalah sebesar 82,67 dengan simpangan baku 7,563

Sebelum diberikan tindakan diperoleh rata-rata pretest siswa kelas kontrol sebesar 28,20 dengan simpangan baku 6,504, setelah 
diajarkan dengan menggunakan model pembelajaran konvensional dari hasil posttest diperoleh data rata-rata kemampuan pemecahan masalah siswa sebesar 76,40 dengan simpangan baku 7,412

Hasil penelitian yang dilakukan di SMK Swasta Asahan Kisaran dari hasil pretest diperoleh rata- rata kemampuan awal kelas eksperimen sebesar 27,87. Berdasarkan rata rata kemampuan awal kedua kelas menunjukkan tidak ada perbedaan yang signifikan antara ratarata kemampuan aal siswa kedua sampel, yang berarti sebelum diberikan perlakuan yang berbeda kemampuan awal siswa kedua kelas adalah sama. Hal ini juga dibuktikan dari hasil perhitungan secara statistic diperoleh $t_{\text {hitung }}<t_{\text {tabel }}$ yaitu $0,000>1,617$.

Setelah diberikan perlakuan yang berbeda yaitu kelas eksperimen (kelas X-AP) diberikan model konvensional. Pada akhir pertemuan setelah semua materi selesai diajarkan siswa diberikan posttest untuk mengukur kemampuan siswa dalam menyelesaikan masalah yang berbentuk soal.

Berdasarkan hasil posttest diperolah kemampuan pemecahan masalah matematika siswa untuk siswa kelas eksperimen rata-rata sebesar 82,67 sedangkan siswa kelas control diperoleh rata-rata kemampuan pemecahan masalah matematika siswa sebesar 77,40. Dengan demikian dapat disimpulkan bahwa terdapat perbedaan kemampuan pemecahan masalah siswa antara siswa eksperimen dengan siswa kelas control. Hal ini juga dibuktikan dari hasil perhitungan sevara statistic dimana $\mathrm{t}_{\text {hitung }}=$ $2,488>t_{\text {tabel }}=1,671$. Yang sekaligus berarti terdapat pengaruh model pembelajaran generatif terhadap pemecahan masalah matematika siswa.
Dangan demikian , berdasarkan penelitian yang dilakukan di SMK Asahan Kisaran, terbukti bahwa terdapat pengaruh penerapan model pembelajaran generative terhadap kemampuan pemecahan masalah matyematika siswa, artinya pembelajaran generative lebih baik dari pembelajaran konvensional.

\section{SIMPULAN DAN SARAN}

\section{Simpulan}

Pada data awal (pretes) pembelajaran kedua kelas sebelum menggunakan model pembelajaran generatif diujikan kedalam uji normalitas dan uji homegenitas dinyatakan data tersebut normalitas dan homegenitas. Hasil data awal pembelajaran diuji kedalam uji t dua pihak untuk mengetahui apakah ada perbedaan pada awal pembelajaran dikelas eksperimen dan kelas control. Pada pemahaman materi persamaan linear dua variabel, dinyatakan $\mathrm{H}_{0}$ diterima dan $\mathrm{H}_{\mathrm{a}}$ ditolak.

Kemudian di tes kembali pada hipotesis akhir pembelajaran (postes) sesudah menggunakan model pembelajaran generatif, hasil data diujikan kedalam uji normalitas dan uji homegenitas, dinyatakan data tersebut normalitas dan homegenitas, kemudian diuji kedalam uji $\mathrm{t}$ dua pihak dinyatakan $\mathrm{H}_{0}$ ditolak $\mathrm{H}_{\mathrm{a}}$ diterima, dengan kata lain bahwa ada pengaruh penggunaan model pembelajaran generatif terhadap pemecahan masalah matematika siswa pada materi persamaan linear dua variabel kelas X SMK Swasta Asahan Kisaran Tahun ajaran 2018/2019.

\section{Saran}

Saran kepada pihak yang terkait dalam proses belajar mengajar matematika diantaranya adalah sebagai berikut: 
1. Bagi guru agar dapat menerapkan model pembelajaran generative dalam pembelajaran matematika pada siswa karena model pembelajaran ini lebih membantu siswa untuk memecahkan masalah matematika siswa khususnya pada materi persamaa linear dua variabel.

2. Bagi siswa agar dapat menggunakan pembelajaran generative sebagai alternative pembelajaran dalam mengerjakan tugas-tugas.

3. Bagi peneliti lanjut, diharapkan agar memperhatikan dan merencanakan alokasi waktu yang cukup banyak dalam pelaksanaannya.
Sukmawarti \& Saragih, Dewi R.S.2012.Evaluasi Proses dan Hasil Belajar Matematika. Medan:Kalangan Sendiri

Sudjimat, Dwi Agus. (1996). Pembelajaran Pemecahan Masalah: Tinjauan Singkat Berdasar Teori Kognitif. Jurnal Pendidikan Humaniora dan Sains. Malang : IKIP Malang.

Sutarman dan Swarsono. 2003.Implementasi Pembelajaran GeneratifBerbasis Kon struktivisme sebagai Upaya Meningkatkan Kemampuan Siswa Kelas III pada Bidang Fisika diSLTP 17 Malang. LemlitUM, Malang

\section{DAFTAR PUSTAKA}

Arikunto, S. 2012. Dasar-dasar Evaluasi Pendidikan. Jakarta: Bumi Aksara.

Arikunto, S. 2006. Prosedur Penelitian. Jakarta: Bumi Aksara.

Israni.2012.58 Model Pembelajaran Inovatif. Medan: Iscom

Soejoko,Edi.2012. Strategi "Think-Talk-Write" Dengan Tugas-Tugas Membaca Untuk Meningkatkan Kemampuan Pemecahan Masalah Matematika Mathematics Paedagogic.11,2.161

Sudjana.2005. Metode Statistika. Bandung: Alfabeta.

Suherman, E. Dan Putra. W. 2003. Strategi Belajar Mengajar Matematika. Jakarta: Universitas Terbuka 